\title{
ASUHAN KEPERAWATAN PADA ANAK DENGAN DENGUE HEMORAGIC FEVER ( DHF )
}

\author{
Welly Andria Mela Sari \\ Akper Kesdam 1/BB Padang Indonesia \\ e-mail korespondensi: Melasarimela2020@gmail.com
}

\begin{abstract}
Abstrak
Dengue Hemorehagic Fever (DHF) atau lebih dikenal dengan Demam Berdarah Dengue (DBD) adalah demam yang disertai pembesaran hati dan pendarahan. Penyakit ini disebabkan oleh virus dengue sejenis virus yang tergolong arbovirus dan masuk kedalam tubuh penderita melalui gigitan nyamuk aedes aegypti. Tujuan dari studi literatur ini adalah u ntuk melakukan studi literature mengeksplorasi penatalaksanan asuhan keperawatan dengan Dengue Hemoragic Fever pada laki-laki dewasa. Desain penelitian ini disusun menggunakan pendekatan metode deskriptif. Metode pengumpulan data yang digunakan dalam penelitian ini adalah metode dokumentasi. Berdasarkan hasil pengkajian didapatkan data pada An.R berumur 7 tahun dimana mengatakan demam selama lebih dari 3 hari, ibu anak mengatakan suhu tubuh An.R panas yaitu suhu tubuh $38.5^{\circ} \mathrm{C}$, sakit kepala, tidak nafsu makan, mual muntah, sakit saat menelan, lemah, nyeri otot dan persendian.
\end{abstract}

Kata Kunci : Asuhan Keperawatan, Keperawatan Anak, diagnosa keperawatan, Dengue Hemorehagic Fever.

\begin{abstract}
Dengue Hemorehagic Fever (DHF) or better known as Dengue Hemorrhagic Fever (DHF) is a fever accompanied by an enlarged liver and bleeding. This disease is caused by the dengue virus, a type of virus that is classified as an arbovirus and enters the patient's body through the bite of the aedes aegypti mosquito. The purpose of this literature study is to conduct a literature study exploring the management of nursing care with dengue hemorrhagic fever in adult males. This research design was prepared using a descriptive method approach. The data collection method used in this research is the documentation method. Based on the results of the study, data on An.R was 7 years old, where the child had a fever for more than 3 days, the child's mother said that An.R's body temperature was hot, namely a body temperature of $38.5{ }^{\circ} \mathrm{C}$, headache, no appetite, nausea, vomiting, pain when swallowing, weakness, muscle and joint pain.
\end{abstract}

Keywords: Nursing Care, Child Nursing, Nursing Diagnosis, Dengue Hemorehagic Fever 


\section{PENDAHULUAN}

\section{Dengue Hemorehagic Fever (DHF)} atau lebih dikenal dengan Demam Berdarah Dengue (DBD) adalah demam yang disertai pembesaran hati dan pendarahan. Penyakit ini disebabkan oleh virus dengue sejenis virus yang tergolong arbovirus dan masuk kedalam tubuh penderita melalui gigitan nyamuk aedes aegypti.

Penyakit ini merupakan satu diantara penyakit yang berhubungan dengan kesehatan masyarakat saat ini. Penyakit ini berhubungan langsung dengan masyarakat dan lingkungan sekitar sehingga dengan mudah peningkatan penularan yang semakin luas. Sejalan dengan peningkatan mobilitas dan kepadatan penduduk.

Insiden penyakit DHF meningkat diseluruh dunia dalam beberapa dekade ini. Populasi diseluruh dunia diperkirakan beresiko terhadap penyakit DHF mencapai 2,5-3 miliar terutama yang tinggal di daerah perkotaan, tropis dan subtropis. Saat ini diperkirakan juga ada 50 juta infeksi dengue yang terjadi di seluruh dunia setiap tahun. Diperkirakan di asia tenggara terdapat 100 juta kasus demam dengue (DD). Dan 500.000 kasus DHF yang memerlukan perawatan di rumah sakit, dan $90 \%$ penderitanya adalah anak-anak yang berusia kurang dari 15 tahun, dan jumlah kematian dari penyakit DHF mencapai 5\% perkiraan setiap tahunnya.

Dikarenakan penyebaran virus dengue yang semakin luas, Asia menempatkan Asia Tenggara pada urutan pertama jumlah penderita demam berdarah ditiap tahunnya. Terhitung sejak tahun 1968 hingga 2009, World Health Organization (WHO) mencatat negara Indonesia sebagai kasus demam berdarah tertinggi di Asia Tenggara.

Dampak yang ditimbulkan oleh virus akut DHF ini adalah sakit kepala,nyeri otot, sendi, dan tulang, serta penurunan jumlah sel darah putih. Dan dampak terbesar dari DHF ini adalah syok hipovolemik, yang disebabkan oleh kebocoran plasma sel akibat kurangnya cairan di dalam tubuh berhubungan dengan ketidak mampuan jantung untuk memasok darah keseluruh tubuh dan apabila tidak tertangani akan menyebabkan kematian.

Maka dari itu peran perawat terhadap dampak masalah tersebut diantaranya memberikan asuhan keperawatan pada klien dengan DHF dengan mengontrol suhu dan nutrisi tentunya membutuhkan keterampilan, kecepatan dan ketepatan perawat dalam memberikan asuhan keperawatan. Dan berperan sebagai edukator atau pendidik terhadap pasien maupun keluarga dengan memberikan penyuluhan kesehatan tentang DHF dan penanggulangannya yaitu pemantauan terhadap lingkungan, penanganan vektor dengan $3 \mathrm{M}$ (mengubur, menguras, dan menutup ), semprot obat nyamuk pagi dan sore.

Berdasarkan latar belakang diatas maka penulis tertarik untuk melakukan penelitian dengan judul Studi Literatur Penatalaksanaan Asuhan keperawatan pada Anak Dengan Dengue Haemoragic Fever (DHF) 


\section{METODE}

Penelitian ini adalah penelitian kualitatif, sampel didalam penelitian diambil hanya satu orang yang akan dilakukan pengkajian terkait Dengue Hemorehagic Fever (DHF).

\section{HASIL PENGKAJIAN}

a) Identitas Klien

Tabel 1

\section{Pengkajian Identitas Klien}

\begin{tabular}{|l|l|}
\multicolumn{1}{|c|}{ Identitas Klien } & \multicolumn{2}{c|}{ An. R } \\
\hline Nama & An. R \\
\hline Umur & 7 Tahun \\
\hline Jenis Kelamin & Laki-Laki \\
\hline Pendidikan & SD \\
\hline Agama & Islam \\
\hline Suku bangsa & Minang \\
\hline Alamat & Jl. Limau Manis \\
\hline Status perkawinan & Pelajar \\
\hline Diagnosa medic & $\begin{array}{l}\text { Deangu Hemoragic } \\
\text { Fever }\end{array}$ \\
\hline Keluhan utama & $\begin{array}{l}\text { Orang tua pas } \\
\text { mengatakan } \\
\text { demam 6 hari. } \\
\text { deman }\end{array}$ \\
\hline Sumber informasi & Tn. H dan Ny S \\
\hline Keluarga terdekat & Ibu \\
\hline Yang dapat dihubungi & Ibu \\
\hline Pendidikan & SMA \\
\hline Pekerjaan & Ibu Rumah Tangga \\
\hline
\end{tabular}

An. R

\begin{tabular}{|c|c|}
\hline $\begin{array}{c}\text { Riwayat } \\
\text { Kesehatan }\end{array}$ & An. R \\
\hline Keluhan Utama & $\begin{array}{l}\text { Orang tua pasien } \\
\text { mengatakan anak demam } \\
\text { lebih dari } 3 \text { hari. }\end{array}$ \\
\hline $\begin{array}{l}\text { Riwayat Kesehatan } \\
\text { Sekarang }\end{array}$ & $\begin{array}{l}\text { Anak pada tanggal } 19 \\
\text { April } 2019 \text { dibawa } \\
\text { kerumah sakit karena } \\
\text { demam sudah lebih dari } 3 \\
\text { hari disertai badan lemah } \\
\text { kemudian anak dibawa ke } \\
\text { IGD, setelah dilakukan } \\
\text { pengkajian } \\
\text { pemeriksaan di IGD } \\
\text { didapatkan suhu tubuh } \\
39^{\circ} \mathrm{C} \text {, HB: } 11,5, \mathrm{HT}: \\
42,1 \text {, leukosit } 2,100, \\
\text { trombosit } 85,000 / \mathrm{mm}^{3}\end{array}$ \\
\hline $\begin{array}{l}\text { Riwayat Kesehatan } \\
\text { Dahulu }\end{array}$ & $\begin{array}{l}\text { Anak pernah menderita } \\
\text { batuk, pilek dan demam } \\
\text { tetapi tidak permah } \\
\text { dirawat di RS }\end{array}$ \\
\hline Riwayat Keluarga & $\begin{array}{l}\text { Tn. } \mathrm{H} \text { dan } \mathrm{Ny} \mathrm{S} \\
\text { mengatakan kelurga tidak } \\
\text { ada menderita penyakit } \\
\text { menular maupun kronis }\end{array}$ \\
\hline
\end{tabular}

\section{Pemeriksaan Fisik}

Tanda-tanda vital

\begin{tabular}{|l|l|}
\hline Suhu & $39^{\circ} \mathrm{C}$ \\
\hline HB & 11,5 \\
\hline HT & 42,1 \\
\hline leukosit & 2,100 \\
\hline trombosit & $85,000 / \mathrm{mm}^{3}$ \\
\hline
\end{tabular}

\section{B. Riwayat Kesehatan}

Tabel 2 Riwayat Kesehatan 
intravaskuler ke ekstravaskuler

\section{PEMBAHASAN}

Berdasarkan studi literatur yang di buat dengan membandingkan dengan hasil penelitian orang lain berupa: jurnal dengan jurnal, artikel dengan artikel ataupun textboox tentang studi literatur. Penatalaksanaan Asuhan Keperawatan Pada Anak dengan Dengue Haemorragic Fever, dapat disimpulkan sebagai berikut:

\section{Pengkajian}

Hasil pengkajian didapatkan dari data pada An.R berumur 7 tahun dimana mengatakan demam selama lebih dari 3 hari, ibu anak mengatakan suhu tubuh An.R panas yaitu suhu tubuh $38.5^{\circ} \mathrm{C}$, sakit kepala, tidak nafsu makan, mual muntah, sakit saat menelan, lemah, nyeri otot dan persendian.

\section{Diagnosa Keperawatan}

Setelah dilakukan pengkajian pada An.R didapatkan diagnosa utama yaitu:

1. Hipertermi berhubungan dengan proses infeksi virus dengue

2. Nyeri akut berhubungan dengan agen cidera biologis (Etiologi).

3. Kekurangan volume cairan berhubungan dengan pindahnya cairan
4. Resiko syok (hypovolemik)berhubungan dengan perdarahan yang berlebihan pindahnya cairan intravaskuler ke ekstravaskuler.

5. Ketidakseimbangan nutrisi kurang dari kebutuhan tubuh berhubungan dengan intake nutrisi yang tidak adekuat akibat mual dan nafsu makan yang menurun

6. Resiko perdarahan berhubungan dengan penurunan faktor pembekuan darah (trombositopeni).

7. Ketidakefektifan bersihan jalan nafas berhubungan dengan penumpukan sekret yang ditandai dengan terdapat suara nafas tambahan(ronchi) pada lapang paru kanan bagian atas, terdapat sekret dihidung, dan pasien tidak dapat mengeluarkan sekret saat batuk masalah belum teratasi, Diagnosa ansietas berhubungan dengan ketakutan yang ditandai dengan anak menangis dan tidak mau disentuh

\section{Intervensi}

Perencanaan Keperawatan yang direncanakan yaitu

1. Memonitor temperature An.R paling sedikit 
setiap 2 jam

2. Memonitor frekuensi pernafasan, nadi dan tekanan darah agar tetap dalam rentang normal

3. Memonitor intake dan ouput An.R sesuai dengan kebutuhan

4. Berikan cairan melalui IV dengan jumlah sesuai dengan anjuran

5. Berikan obat Anti piretik dengan dosis sesuai anjuran dokter

6. Berikan kompres air hangat pada lipat paha dan aksila An.R

7. Memonitor komplikasi terkait demam(kejang, penurunan kesadaran, status ketidak normalan elektrolit, ketidakseimbangan asam basa)

8. Fasilitas konsumsi cairan sesuai anjuran dan kebutuhan An.R

\section{Implementasi}

Implementasi keperawatan disesuaikan rencan tindakan yang yang telah disusun, Yaitu Dalam mengatasi masalah keperawatan hipertermi pada anak $\mathrm{R}$ yaitu dengan memonitor suhu tubuh, memberikan anti piretik, memberikan anak kompres hangat, serta kolaborasikan dalam pemberian cairan, meningkatkan intake cairan serta kolaborasikan dalam pemberian obat obatan farmakologi PCT (PO) 3 x $1250 \mathrm{mg}$, Sampicilin (IV) 3 x 500 mg RL (IVFD) 18 / tpm.

\section{Evaluasi}

Akhir dari proses keperawatan adalah evaluasi yaitu evaluasi terhadap asuhan keperawatan, pada evaluasi studi literatur ini dengan diagnosa keperawatan DHF dengan masalah keperawatan hipertermi dengan implementasi yang telah diuraikan dengan contoh kasus telah teratasi sesuai dengan kriteria hasil.

\section{DAFTAR PUSTAKA}

Aziz Alimul, 2008. Pengantar ilmu keperawatan anak. Jakarta : Salemba Medika

Alimul Aziz, 2014. Metode Penelitian Keperawatan dan Kebidanan. Jakarta : Salemba Medika

Boru Saragi, Ade Rooslianta,2018, Karya Tulis Ilmiah Asuhan Keperawatan pada An.M. T. Dengan Demam Berdarah Dengue di ruangan Mawar RSUD.

\section{Prof.dr.W.Z.Johannes kupang}

Marni, 2016. Asuhan keperawatan anak pada penyakit tropis. Jakarta : Elangga

Nadesul, Handrawan, 2016. Kiat mengalahkan demam berdarah dan virus zika. Kompas. Jakarta.

Nugrahajati, Paulus, 2012. Thypus, DBD, Malaria. Jakarta selatan : PT wahyu media 
Jurnal Ilmiah Cerebral Medika, Vol.1.No 2

Vol.1.No 2 ( 2019) p-ISSN :2657-2435 
Jurnal Ilmiah Cerebral Medika, Vol.1.No 2

Vol.1.No 2 ( 2019)

p-ISSN :2657-2435 